\title{
Identifikasi Permasalahan Pembelajaran IPA Pada Siswa Kelas III SDN Buluh 3 Socah
}

\author{
Cherly Ana Safira $^{1)^{*}}$, Agung Setyawan ${ }^{1)}$, Tyasmiarni Citrawati ${ }^{1)}$ \\ ${ }^{1)}$ Universitas Trunojoyo Madura, Jawa Timur, Indonesia \\ *cherlyanasafira@gmail.com
}

\begin{abstract}
Abstrak: Penelitian ini adalah studi awal dalam Identifikasi permasalahan yang dihadapi pada mata pelajaran IPA siswa kelas III di SDN Buluh 3 Socah. Tujuan penelitian ini yaitu untuk mengidentifikasi hasil belajar IPA pada siswa kelas III SDN Buluh 3 Socah dan upaya untuk mengatasi permasalahan yang dihadapi oleh siswa dan guru. Jenis penelitian ini menggunakan penelitian kuantitatif deskriptif. Populasi pada penelitian ini adalah seluruh siswa kelas III di SDN Buluh 3 Socah yang terdiri dari 30 siswa. Sampel dalam penelitian ini menggunakan sampling jenuh yang merupakan semua anggota populasi digunakan sebagai sampel. Teknik pengumpulan data yang dilakukan dalam penelitian ini adalah wawancara, observasi dan tes. Instrumen yang digunakan yaitu pedoman wawancara, pedoman observasi, dan lembar tes. Berdasarkan hasil observasi di kelas III menunjukkan proses pembelajaran menggunakan model pembelajaran konvensional. Sedangkan hasil tes menunjukkan hasil belajar siswa pada muatan pelajaran IPA presentase ketuntasannya 17\% yaitu hanya ada 5 siswa dari 30 siswa yang lulus diatas KKM. Hal itu menunjukkan hasil belajar siswa rendah.
\end{abstract}

Kata Kunci: Belajar, Hasil Belajar, IPA

\section{Pendahuluan}

Pembelajaran merupakan ujung tombak dari proses pendidikan dalam sebuah lembaga pendidikan. pembelajaran yaitu suatu perubahan dalam pengetahuan, keterampilan dan sikap serta kriteria bagi pembelajaran (Dadri, et al, 2019). Sedangkan menurut Mujtahidin mengemukakan bahwa pembelajaran merupakan proses interaksi yang dilakukan oleh guru dengan peserta didik dengan menggunakan berbagai sumber belajar sebagai bahan kajian (Mujtahidin 2017). Pembelajaran mengandung arti bahwa adanya kegiatan belajar mengajar (KBM). Tugas seorang peserta didik dari pembelajaran di sekolah yaitu untuk belajar. Menurut Pane \& Muhammad (2017) menyatakan bahwa belajar merupakan terjadinya perubahan sebuah proses perilaku terhadap hasil interaksi antara individu dengan lingkungannya. Perubahan perilaku yang tercermin dari hasil belajar dapat bersifat continiu, positif, tearah, fungsional serta aktif.

Menurut Ainurrahman juga mengemukakan bahwa belajar dapat menunjukkan sebuah aktivitas seseorang yang dilakukan secara sengaja dan sadar (Pane \& Muhammad, 2017). Aktivitas yang dimaksudkan merupakan keaktifan seseorang dalam melakakukan sebuah perubahan pada dirinya melalui aspek mental yang ada pada dirinya sendiri. Berdasarkan hal tersebut, maka dapat diartikan bahwa kegiatan belajar yang baik jika intensitas keaktifan mental dan jasmaninya seseorang semakin tinggi atau meningkat. Namun, jika seseorang dengan keaktifan mental serta jasmaniahnya menurun maka proses kegiatan belajar dapat dikatakan kurang baik atau kurang maksimal.

Ilmu Pengetahuan Alam (IPA) merupakan ilmu pengetahuan alam yang berkaitan dengan kehidupan manusia secara langsung serta mempelajari segala sesuatu yang ada pada alam semesta. IPA berisi sekumpulan pengetahuan yang berupa fakta-fakta, prinsip-prinsip, konsep-konsep serta proses penemuan dan memiliki sikap ilmiah (Dewana, 2017). Pada dasarnya pembelajaran IPA juga dapat digunakan sebagai sebuah pemecahan masalah-masalah yang dapat diidentifikasika dalam kehidupan sehari-hari.

Menurut Rahma menyatakan bahwa Ilmu Pengetahuan Alam (IPA) merupakan sebuah muatan mata pelajaran yang harus dipelajari oleh peserta didik baik itu dalam jenjang sekolah dasar hingga jenjang sekolah menengah ke atas karena IPA berkaitan langsung dengan kehidupan sehari-hari yang ada disekitar kita (Rahma, 
et al, 2017). Hal ini sesuai dengan pendapat dari Samatoa yang mengemukakan bahwa dalam IPA mempelajari tentang sesuatu yang berhubungan dengan gejala-gejala alam secara sistematis melalui sebuah percobaan pengamatan yang telah dilakukan oleh manusia (Nahdi, et al, 2018). Pembelajaran IPA menekankan pada proses percobaan yang dapat menghubungkan pengetahuan (kognitif) awal siswa dengan materi yang akan dipelajari dalam kelas. Hal tersebut dikarenakan dalam pembelajaran IPA dapat meningkatkan proses berpikir peserta didik dalam memahami konsep dan dapat diterapkan atau diaplikasikan kedalam kehidupan sehari-hari.

Pembelajaran IPA bertujuan membantu siswa dalam memahami konsep IPA yang berhubungan dengan fenomena alam, dapat menerapkan dalam kehidupan nyata sehari-hari serta dapat mengambangkan keterampilan, menanamkan sikap ilmiah pada diri peserta didik. Pembelajaran IPA secara bermakna mampu mengaktifkan siswa dalam penguasan konsep dan mampu menerapkan ilmunya pada kehidupan sehari-hari, dengan demikian maka pengaruh guru sangat berperan penting dalam proses pembelajaran. Guru harus mampu menyajikan sebuah pembelajaran yang juga melibatkan siswa secara langsung. Namun, dalam kenyataannya ketika proses pembelajaran IPA berlangsung banyak pembelajarannya yang dilakukan secara konvensional dimana pembelajaran berpusat pada guru dan berjalan satu arah tanpa melibatkan siswa secara langsung yang dapat mengakibatkan pembelajaran secara pasif (Nahdi, et al, 2018).

Pembelajaran IPA di Sekolah Dasar pada kelas III tema 6 (Energi dan Perubahannya), sub tema 1 (Sumber Energi), pembelajaran 1 memuat materi tentang sumber dan bentuk energi. Energi merupakan suatu kemampuan untuk melakukan sebuah usaha. Segala sesuatu mengenai benda dan dapat menghasilkan sebuah energi maka dapat dikatakan sebagai sumber energi. Air dan udara merupakan sumber energi, tumbuhan dan hewan adalah sebagai sumber makanan sedangkan makanan merupakan sumber energi yang dibutuhkan oleh tubuh manusia. Jadi, tumbuhan dan hewan juga sebagai energi. Sumber energi lainnya yang ada di bumi yaitu matahari, matahari merupakan sumber energi terbesar yang ada dibumi karena dapat mengahasilkan energi cahaya dan panas yang menjadi sumber kehidupan di bumi (Suwarsono, et al, 2013, p. 13).

Sumber energi yang terbesar yaitu matahari, matahari memberikan manfaat yang sangat besar bagi kehidupan dimuka bumi ini seperti matahari sangat dibutuhkan pada proses fotosintesis pada tumbuhan, dapat mengeringkan baju, menjemur ikan dan lain-lain. Bentuk-bentuk energi yang dihasilkan dan banyak digunakan dalam kehidupan sehari-hari yaitu seperti energi panas, energi bunyi, energi gerak, energi listrik, energi kinetik, energi kimia dan lain-lain (Ambarwati, 2015).

Pembelajaran yang dilaksanakan oleh guru berpengaruh terhadap keberhasilan pembelajaran IPA di sekolah dasar. Guru di tuntun dapat menyampaikan materi semenarik mungkin agar siswa dapat tertarik dan tidak merasa bosan dalam proses pembelajaran. Selain itu proses pembelajaran yang dilakukan oleh guru harus mencapai tujuan pembelajaran dan hasil belajar siswa yang baik. Agar pembelajaran dapat berjalan dengan optimal guru dapat menggunakan metode, media pembelajaran dan model-model pembelajaran inovatif.

Berdasarkan hasil wawancara dan observasi yang dilakuakan kepada guru kelas III SDN Buluh 3 Socah diperoleh informasi bahwa dalam pembelajaran guru masih menerapkan pembelajaran konvensional. Guru menjelaskan materi pelajaran kemudian memberikan penugasan soal yang ada dalam buku tema. Siswa pasif dalam pembelajaran. Hanya beberapa siswa yang memperhatikan guru dalam proses pembelajaran, terdapat juga siswa yang suka asyik main sendiri dan ada beberapa anak yang mengantuk pada saat proses pembelajaran. Selain itu guru juga kesulitan dalam mengondisikan siswa dalam pembelajaran karena jumlah siswa yang sangat banyak yaitu 30 siswa dan hasil belajar (kognitif) siswa kurang dari nilai KKM. Hasil belajar siswa pada muatan pelajara IPA presentse ketuntasanya $17 \%$ yaitu hanya ada 5 siswa dari 30 siswa yang lulus diatas KKM. Hal ini menunjukkan hasil belajar siswa rendah dan tujuan pembelajaran belum terlaksana dengan baik.

Hasil belajar merupakan bagian terpenting dalam berubahnya tingkah laku individu. Menurut Sudjana mengemukakan bahwa hasil belajar merupakan sebuah proses perubahan tingkah laku yang dapat mencakup kedalam aspek konitif, afektif serta psikomotor (Sudjana 2009). Hasil belajar merupakan sebuah pencapaian yang dilakukan oleh peserta didik setelah terjadinya proses belajar. Masing-masing peserta didik memiliki pencapaian atau hasil belajar yang berbeda-beda (Handayani, et al, 2017).

Menurut Nurhadi dalam mengemukakan bahwa hasil belajar merupakan sebuah pencapaian prestasi yang diperoleh anak berupa nilai mata pelajaran (Syafaruddin, et al, 2019). Dengan arti lain hasil belajar merupakan prestasi dalam perubahan diri individu sebagai hasil dari aktivitas belajar. Hasil belajar juga dapat diartikan 
sebagai pencapaian siswa berupa perolehan atau taraf kemampuan dalam mengikuti proses pembelajaran secara singkat dengan terjadinya perubahan tingkah laku, keterampilan atau pengetahuan yang kemudian dapat diukur dan dinilai dengan wujud angka atau pernyataan. Hasil belajar pada ranah kognitif terdapat aspek memahami, yang berarti mempelajarai tentang membangun sebuah makna yang ada dalam suatu materi pelajaran yang telah dipelajari dari penyampaian guru dalam pembelajaran (Nurmisantri, 2017).

Berdasarkan hal tersebut, dapat disimpulkan bahwa hasil adalah sebuah gambaran kemampuan peserta didik yang diperoh dari konsekuensi penilaian proses belajar siswa suatu capaian yang telah diraih seseorang, bagaimanapun keadaannya dan didapatkan dengan adanya usaha terlebih dahulu. Salah satu faktor yang dapat mempengaruhi hasil belajar peserta didik yaitu guru serta cara mengajarnya. Untuk itu guru perlu mengetahui cara yang tepat untuk meningkatkan hasil belajar siswa (Syahputra, 2020). Sedangkan menurut Djamarah (dalam Syafaruddin, et al, 2019) menyebutkan bahwa faktor-faktor yang mempengaruhi hasil belajar dapat dibagi menjadi tiga yaitu: faktor individu, faktor stimulus dan.

Faktor individual ini sangat berpengaruh terhadap kegiatan belajar siswa, yaitu dengan adanya pertumbuan dan usia atau terjadinya pertumbuhan dan perkembangan pada diri individu. Semkin dewasa individu maka semakin meningkat pula kematangan berbagai fungsi fisiologisnya. Faktor stimulus adalah faktor yang berasal dari luar individu yang dilakukan guna mengadakan reaksi atau perubahan penegasan serta susunan lingkungan eksternal yang diterima. faktor perencangan pembelajaran, metode yang dilakukan guru dalam kegiatan belajar mengajar sangat berpengaruh terhadap belajar siswa, dengan kata lain perancangan pembelajaran yang gunakan guru sangat menentukan dalam mencainya hasil belajar siswa yang sesuai diharapkan. Guru dapat merancang pembelajaran mulai dari model yang efektif, serta inovatif agar peserta didik dapat tertarik sehingga terjadinya proses belajar yang menghasilkan hasil belajar yang baik.

Berdasarkan hal tersebut, maka tujuan dari penelitian studi pendahuluan ini yaitu untuk mengidentifikasi hasil belajar IPA pada siswa kelas III SDN Buluh 3 Socah dan upaya dalam mengatasi permasalahan yang dihadapi oleh siswa dan guru. Informasi yang diperoleh penting untuk mengetahui hal-hal apa saja yang menyebabkan rendahnya hasil belajar IPA, sehingga dapat menentukan strategi atau model pembelajaran apa yang tepat untuk mencegah rendahnya hasil belajar siswa di SDN Buluh 3 Socah. Berdasarkan masalah yang telah dipaparkan, maka peneliti melakukan penelitian yang berjudul "Identifikasi Permasalahan Pembelajaran IPA pada Siswa Kelas III SDN Buluh 3 Socah”.

\section{Metode}

Jenis penelitian yang digunakan dalam penelitian studi pendahuluan ini adalah penelitian kuantitatif dengan menggunakan metode penelitian deskriptif. Menurut Nasir penelitian kuantitatif deskriptif bertujuan untuk menggambarkan segala sesuatu secara terstruktur, faktual, serta secara akurat mengenai fakta, sifat, dan hubungan fenomena yang diselidiki (Rukajat, 2018). Penelitian ini dilaksanakan pada tanggal 21 Februari hingga selesai dan dilaksanakan di kelas III SDN Buluh 3 Kecamatan Socah, Kabupaten Bangkalan Madura. Populasi pada penelitian ini adalah seluruh siswa kelas III di SDN Buluh 3 Socah yang terdiri dari 30 siswa. Sampel dalam penelitian studi pendahuluan ini menggunakan sampling jenuh, yang berarti peneliti dapat menggunakan semua anggota populasi untuk dijadikan sebuah sampel (Sugiyono, 2012). Sampel penelitian studi pendahuluan ini adalah siswa kelas III SDN Buluh 3 Socah terdiri dari 17 siswa laki-laki dan 13 siswa perempuan.

Teknik pengumpulan data yang akan dilakukan dalam penelitian ini meliputi (1) Wawancara, (2) Observasi, dan (3) Tes. Instrumen penelitian yang digunakan yaitu lembar wawancara, pedoman observasi dan lembar soal tes. Lembar wawancara digunakan untuk memperoleh informasi dari guru secara langsung. Pedoman observasi digunakan untuk mengamati proses kegiatan belajar mengajar guru dan siswa. Lembar tes hasil belajar berupa tes pilihan ganda guna mengetahui hasil belajar (kognitif) siswa kelas III SDN Buluh 3 Socah. Sedangkan teknik analisis data pada penilitian ini menggunakan reduksi data, analisis data dan verifikasi atau penarikan kesimpulan.

\section{Hasil dan Pembahasan}

Berdasarkan hasil penelitian yang dilakukan oleh peneliti di SDN Buluh 3 Socah ada beberapa data yang terkumpul dari instrumen wawancara, lembar observasi dan tes hasil belajar (Kognitif) siswa. Lembar instrumen wawancara yang dilakukan peneliti dengan guru kelas III SDN Buluh 3 Socah dapat dilihat pada table 1. 
Berdasarkan hasil wawancara guru kelas III SDN Buluh 3 Socah yang telah dilakukan ada beberapa permasalahan pada pembelajaran Ilmu Pengetahuan Alam (IPA) yaitu kurangnya minat belajar siswa dalam pelajaran IPA, guru hanya menggunakan pembelajaran yang konvensional sehingga siswa sulit memahami matari yang telah disampaikan guru, minimnya penggunaan media pembelajaran yang dapat mendukung proses pembelajaran, hal tersebut yang menyebabkan hasil belajar IPA siswa kurang memenuhi nilai KKM.

Tabel 1. Hasil Wawancara Guru Kelas III SDN Buluh 3 Socah

\begin{tabular}{|c|c|c|}
\hline No & Wawancara & Jawaban \\
\hline 1 & $\begin{array}{l}\text { Strategi/model/metode pembelajaran } \\
\text { apa yang ibu gunakan dalam } \\
\text { pembelajaran di kelas pada pembelajaran } \\
\text { IPA? }\end{array}$ & $\begin{array}{l}\text { Dalam pembelajaran IPA biasanya menggunakan metode ceramah. } \\
\text { Proses belajar mengajar dilakukan dengan cara duduk berkelompok } \\
\text { tetapi belum menggunakan model kooperatif yang ditepakan secara } \\
\text { semestinya. }\end{array}$ \\
\hline 2. & $\begin{array}{l}\text { Kalau untuk media pembelajaran ibu } \\
\text { apakah ibu menggunakan media } \\
\text { pembelajaran dalam pembelajaran } \\
\text { matematika? }\end{array}$ & $\begin{array}{l}\text { Dalam pembelajaran jarang menggunakan media pembelajaran } \\
\text { karena fasilitasnya kurang mendukung, jadi saya menggunakan } \\
\text { media seadanya seperti media cetak gambar saja atau bisa juga } \\
\text { dengan memanfaatkan barang yang ada disekitar sesuai dengan } \\
\text { materi yang akan dipelajari. }\end{array}$ \\
\hline 3. & $\begin{array}{l}\text { Permasalahan apa saja yang dihadapi guru } \\
\text { dalam menyampaikan pembelajaran IPA? }\end{array}$ & $\begin{array}{l}\text { Permasalahan yang ada dalam siswa kelas III ini siswa kurang minat } \\
\text { belajar dalam pembelajaran IPA sehingga materi yang sudah } \\
\text { disampaikan guru siswa terkadang kurang memahaminya, terlebih } \\
\text { lagi hasil belajar siswa di kelas III ini bisa dibilang cukup rendah. }\end{array}$ \\
\hline 4. & $\begin{array}{l}\text { Permasalahan apa saja yang dialami siswa } \\
\text { dalam tentang energi? }\end{array}$ & $\begin{array}{l}\text { Menurut saya, pembelajaran IPA itu sangat mudah karena kita bisa } \\
\text { melihat penerapan atau contoh-contoh dalam kehidupan sehari-hari } \\
\text { seperti dalam materi tentang energi yaitu sumber dan bentuk energi, } \\
\text { materi tersebut bisa diterapkan dalam kehidupan kita seperti } \\
\text { menjemur baju dibawah sinar matahari. Tetapi kenapa siswa masih } \\
\text { merasa kesulitan akan materi tersebut. }\end{array}$ \\
\hline 5. & $\begin{array}{l}\text { Untuk menghadapi siswa yang sulit dalam } \\
\text { memahami materi pada pembelajaran } \\
\text { IPA, solusi apa yang ibu berikan? }\end{array}$ & $\begin{array}{l}\text { Solusi dalam hal tersebut yaitu dengan selalu memberikan motivasi } \\
\text { agar minat belajar siswa meningkat sehingga mampu memenuhi } \\
\text { tujuan pembelajaran dan mampu meningkatkan hasil belajar siswa. }\end{array}$ \\
\hline
\end{tabular}

Berikut merupakan penyajian hasil pengamatan (observasi) di kelas III SDN Buluh 3 Socah dalam mata pelajaran IPA.

Tabel 2. Hasil Pengamatan (Observasi)

\begin{tabular}{|c|c|c|c|}
\hline \multirow{2}{*}{ No. } & \multirow{2}{*}{ Aspek yang diamati } & \multicolumn{2}{|c|}{ Kegiatan Siswa } \\
\hline & & Muncul & Tidak Muncul \\
\hline \multicolumn{4}{|c|}{ GURU } \\
\hline 1 & Guru menggunakan model pembelajaran & & $\checkmark$ \\
\hline 2 & Guru menggunakan metode pembelajaran & $\checkmark$ & \\
\hline 3 & Guru menggunakan media pembelajaran & & $\checkmark$ \\
\hline 4 & Pembelajaran berpusat pada peserta didik & & $\checkmark$ \\
\hline \multicolumn{4}{|c|}{ SISWA } \\
\hline 1 & Siswa bertanya pada guru & & $\checkmark$ \\
\hline 2 & Siswa menjawab pertanyaan guru & $\checkmark$ & \\
\hline 3 & Siswa menjawab pertanyaan dari teman & & $\checkmark$ \\
\hline 4 & Siswa memberikan pendapat dalam diskusi & & $\checkmark$ \\
\hline 5 & Siswa menyelesaikan tugas yang diberikan guru & $\checkmark$ & \\
\hline 6 & Ketepatan siswa dalam mengumpulkan tugas & $\checkmark$ & \\
\hline
\end{tabular}

Berdasarkan hasil observasi yang dilakukan peneliti pada kelas III SDN Buluh 3 Socah yaitu ketika proses kegiatan belajar mengajar berlangsung guru hanya menggunakan pembelajaran konvensional seperti metode ceramah. Proses belajar mengajar yang dilakukan guru hanya menjelaskan materi pembelajaran kemudian memberikan penugasan soal yang ada dalam buku tematik. Proses belajar mengajar dilakukan dengan cara duduk berkelompok tetapi belum menggunakan model kooperatif yang ditepakan secara semestinya. Pembelajaran di kelas belum menunjukkan student center lerning tetapi lebih kepada teacher center learning karena pembelajaran berpusat pada guru. Dalam proses pembelajaran siswa terlihat pasif, sehingga guru harus mendorong siswa agar 
aktif dalam bertanya atau dalam pembelajaran. Selain itu banyak siswa yang tidak memperhatikan guru pada saat menyampaikan materi. Sebagian siswa ada yang mengobrol dengan teman sebangkunya, berbuat gaduh dan bermain sendiri bahkan ada yang mengantuk. Hal tersebut membuat siswa tidak memahami materi yang diajarkan dan berdampak pada hasil belajarnya rendah.

Berdasarkan hasil pretest yang dilakukan peneliti data nilai mata pelajaran IPA yang diperoleh siswa kelas III SDN Buluh 3 Socah menunjukkan rata-rata nilai masih banyak yang dibawah KKM. KKM untuk mata pelajaran IPA sendiri adalah 65. Peneliti membuat 20 soal pilihan ganda mata pelajaran IPA tentang sumber dan bentuk energi. Data pendukung mengenai hasil belajar IPA siswa SDN Buluh 3 Socah sebagai subjek ditunjukkan pada tabel yaitu:

Tabel 3. Data Test Hasil Belajar Siswa Kelas III SDN Buluh 3 Socah

\begin{tabular}{clccl}
\hline No & \multicolumn{1}{c}{ Nama } & KKM & Nilai & Keterangan \\
\hline 1 & Achmad Fikri Maulana & 65 & 55 & Tidak Lulus \\
2 & Ainul Yakin & 65 & 45 & Tidak Lulus \\
3 & Alfin Anillah & 65 & 60 & Tidak Lulus \\
4 & Anas Kafin & 65 & 70 & Lulus \\
5 & Ansor & 65 & 55 & Tidak Lulus \\
6 & Asyifatul Hasanah & 65 & 25 & Tidak Lulus \\
7 & Danyl & 65 & 65 & Lulus \\
8 & Dewi Nabila & 65 & 65 & Lulus \\
9 & Dhila Permatasari & 65 & 35 & Tidak Lulus \\
10 & Imroatus Sholiha & 65 & 70 & Lulus \\
11 & Lailatul Hafizah & 65 & 35 & Tidak Lulus \\
12 & M Rosi & 65 & 40 & Tidak Lulus \\
13 & Marah Konita Tillah & 65 & 50 & Tidak Lulus \\
14 & Moh Fadil Ilham & 65 & 40 & Tidak Lulus \\
15 & Moh Farhan & 65 & 40 & Tidak Lulus \\
16 & Moh Faris & 65 & 35 & Tidak Lulus \\
17 & Mohammad Iqbal Azzahir & 65 & 35 & Tidak Lulus \\
18 & Mohammad Riansyah & 65 & 30 & Tidak Lulus \\
19 & Mohammad Vitra K & 65 & 20 & Tidak Lulus \\
20 & Mohammad Alif Firdaus & 65 & 50 & Tidak Lulus \\
21 & Nuri Nabilatul Kalima & 65 & 50 & Tidak Lulus \\
22 & Putra Romadani & 65 & 25 & Tidak Lulus \\
23 & Robiatul Adewiyah & 65 & 60 & Tidak Lulus \\
24 & Sabrina Az-Zahra Rasul & 65 & 40 & Tidak Lulus \\
25 & Siti Maryam & 65 & 20 & Tidak Lulus \\
26 & Slamet Riyadi & 65 & 35 & Tidak Lulus \\
27 & Sofia & 65 & 5 & Tidak Lulus \\
28 & Ubaidurrohman & 65 & 75 & Lulus \\
29 & Wahyu Abdulloh Afandi & 65 & 30 & Tidak Lulus \\
30 & Wirda Chairul Akbar & 65 & 40 & Tidak Lulus \\
\hline & & & &
\end{tabular}

$\square$ Nilai diatas KKM $\square$ Nilai Setara KKM $\square$ Nilai dibawah KKM

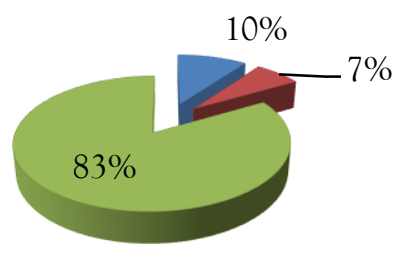

Gambar 1. Presentase Hasil Belajar IPA Siswa Kelas III SDN Buluh 3 Socah

Keterangan:

KKM $: 65$ 
Tuntas $\quad: 5$ siswa

Tidak Tuntas : 25 siswa

Presentase hasil belajar siswa, dihitung menggunakan rumus sebagai berikut:

$$
N=\frac{\text { Jumlah Siswa Yang tuntas }}{\text { Jumlah Siswa }} \times 100 \%
$$

Dari tabel diatas menunjukkan bahwa siswa kelas III SDN Buluh 3 Socah berjumlah 30 orang yaitu lakilaki 17 dan perempuan 13. Tabel diatas juga menunjukkan nilai test hasil belajar (kognitif) menunjukkan bawah dari 30 siswa kelas III SDN Buluh 3 Socah tahun 2019/2020 dengan Nilai standar KKM 65 hanya 17\% yaitu 5 siswa yang tuntas dengan 3 orang siswa yang mendapatkan nilai diatas KKM dan 2 siswa yang mendapatkan nilai setara dengan KKM, sedangkan 25 siswa yang yang belum tuntas. Berdasarkan hal tersebut, maka tujuan penelitian studi pendahuluan ini yaitu untuk mengidentifikasi hasil belajar IPA pada siswa kelas III SDB Buluh 3 Socah dan upaya dalam mengatasi permasalahan yang dihadapi oleh siswa dan guru. Informasi yang diperoleh penting untuk mengetahui hal-hal apa saja yang menyebabkan rendahnya hasil belajar IPA, sehingga dapat menentukan strategi atau model pembelajaran yang sesuai untuk mencegah rendahnya hasil belajar yang dapat mendukung proses pembelajaran.

\section{Simpulan}

Berdasarkan hasil penelitian yang dilakukan pada saat studi pendahuluan dapat ditarik simpulan bahwa hasil belajar siswa kelas III SDN Buluh 3 Socah terbilang sangat rendah pada muatan IPA. Permasalahan teridentifikasi karena adanya faktor yang menyebabkan rendahnya hasil belajar IPA yaitu guru kurang bervariatif dan efisien menggunakan sebuah model atau metode pembelajaran (biasanya menggunakan pembelajaran konvensional), media pembelajaran guna menunjang proses pembelajaran dan keaktifan siswa di kelas khususnya dalam muatan pembelajaran IPA materi sumber dan bentuk energi.

Berdasarkan hasil belajar siswa kelas III di SDN Buluh 3 Socah yang berjumlah 30 siswa dengan 17 siswa laki-laki dan 13 siswa perempuan, menyatakan bahwa presentase hasil belajar IPA yaitu 17\%, dengan keterangan hanya terdapat 5 siswa yang yang lulus dengan keterangan 3 anak yang memiliki nilai diatas KKM, dan dua anak dengan nilai pas KKM. Selebihnya berada dibawah KKM yang berjumlah 25 siswa. Hal tersebut menunjukkan bahwa hasil belajar IPA sangat rendah.

\section{Daftar Pustaka}

Ambarwati, D. (2015). Bimbel Rahasia Inti IPA Terpadu SD. Ozproduction.

Dadri, P. C. W., Dantes, N., \& Gunamantha, I. M. (2019). Pengaruh Model Pembelajaran Kooperatif Tipe NHT terhadap Kemampuan Berpikir Kritis dan Hasil Belajar Matematika Siswa Kelas V SD Gugus III Mengwi. PENDASI: Jurnal Pendidikan Dasar Indonesia, 3 (2), 84-93.

Dewana, A. (2017). Pengaruh Model Problem Based Learning Terhadap Hasil Belajar IPA Kelas IV SD.

Handayani, T., dkk. (2017). Penerapan Model Kooperatif Tipe Snowball Throwin Belajar Peserta Didik. Jurnal Curricula, 2 (1), 22.

Mujtahidin. (2017). Teori Belajar dan Pembelajaran. Surabaya: Pena Salsabila.

Nahdi, D. S., Yonanda, D. A., \& Agustin, N. F. (2018). Upaya Meningkatkan Pemahaman Konsep Siswa Melalui Penerapan Metode Demonstrasi Pada Materi Pembelajaran IPA. Jurnal Cakrawala Pendas, 4 (2), 9-16.

Nurmisantri. (2017). Identifikasi Hasil Belajar Ranah Kognitif Siswa pada Materi Fluida Statis. Jurnal Ilmu Pendidikan Fisika, 2 (1), 17.

Pane, A., \& Muhammad, D. D. (2017). Belajar dan Pembelajaran. FITRAH Jurnal Kajian Ilmu-Ilmu Keislaman, 3 (2), 333-352.

Rahma, S., Yuliati, L., \& Irawan, E. B. (2017). Penguasaan Konsep IPA pada Siswa Sekolah Dasar. Prosiding SEMNAS PS2DMP UML, 3 (1).

Rukajat, A. (2018). Pendekatan Penelitian Kuantitatif. Yogyakarta: Deepublish. 
Sudjana, N. (2009). Penilaian Hasil Proses Belajar Mengajar. Jakarta: PT Remaja Rosdakarya.

Sugiyono. (2012). Metode penelitian kuantitatif dan REDD. Bandung: Alfabet.

Suwarsono., dkk. (2013). Tematik Terpadu Kurikulum 13: Energi dan Perubahannya Buku Guru. Jakarta: Kementerian Pendidikan dan Kebudayaan.

Syafaruddin., Supiono., \& Burhanuddin. (2019). Guru, Mari Kita Menulis Penelitian Tindakan Kelas (PTK). Yogyakarta: CV Budi Utama.

Syahputra, E. (2020). Snowball Throwing Tingkatkan Minat dan Hasil Belajar. Sukabumi: Haura. 